\title{
Analysis of Influence Dimensions of the Gate on the Homogeneity of the Low Weight Castings Made of Silumin
}

\author{
Ján Majerník ${ }^{1}$, Ján Kmec ${ }^{1}$, Miroslav Gombár ${ }^{1}$, Michal Halapi ${ }^{2}$ \\ ${ }^{1}$ Institute of Technology and Business in České Budějovice, Okružní 517/10, 370014 České Budějovice, Czech Republic, \\ E-mail: majernik@mail.vstecb.cz \\ ${ }^{2}$ The Technical University of Košice, Faculty of Manufacturing Technologies with a seat in Prešov, Bayerova 1, 08001 \\ Prešov, Slovak Republic, E-mail: michal.halapi@tuke.sk
}

The design of the gating system is a major factor in the internal homogeneity for casting. A properly designed system should ensure a proper and continuous filling of cavities in a mold. A continuous filling in a mold cavity gives the initial condition for internal soundness and homogeneity when casting, which in turn is reflected in the quality and mechanical properties. The geometry and shape of the gate models and directs the melt stream entering the mold cavity, this greatly affect the properties of the castings. Homogeneity of castings closely correlates with the mechanical properties of castings. The present paper is devoted to analyzing the effect of the dimensions of the inlet slit on the homogeneity of the casting. As the width of the gully is constant according to the design method of the ingate systems, the variable parameter was the height of the gate. The aim of the experiments was to find the most advantageous height of the gate that is necessary to achieve the lowest porosity values. The boundary values of the height of the gate were determined based on the numerical design of the ingate system for the particular casting and the NovaFlow \& Solid simulation program. The porosity analysis $f$ was performed by the OLYMPUS GX51 microscope and the evaluation of the samples was carried out using the ImageJ computer program.

Keywords: die casting, homogeneity, porosity

\section{References}

[1] PAŠKO, J., GAŠPÁR, Š. (2014). Technological factors of die casting. 1st ed. 2014. ISBN 978-3-942303-25-5.

[2] RUŽBARSKÝ, J., PAŠKO, J., GAŠPÁR, Š. (2014). Techniques of Die Casting. 1st ed. 2014. ISBN 978-3942303-29-3.

[3] GAŠPÁR, Š., PAŠKO, J. (2015). Technológia výroby hliníkových odliatkov tlakovým liatím. 1st ed. 2015. ISBN 978-80-553-2236-0.

[4] GAŠPÁR, Š., PAŠKO, J., MAJERNÍK, J. (2016). Specific Pressure and Mechanical Properties of the Alternator Flange from EN AC 47100 Alloy in HPDC Technology. TEM Journal, 2016, vol. 5, no. 2, p. 160-164. ISSN 2217-8309

[5] MAJERNÍK, J. (2016). Výskum vplyvu konštrukčných úprav vtokového systému tlakovej formy na kvalitu odliatkov: Dizertačná práca. Prešov: Fakulta výrobných technológií so sídlom v Prešove, 2016

[6] MAJERNÍK, J., GERKOVÁ, J. (2014). Vplyv konštrukcie vtokového systému na kvalitu odliatkov. Posterus.sk, 2014, vol. 7, no. 8, p. 1-5. ISSN 1338-0087

[7] BOLIBRUCHOVÁ, D., BRŮNA, M. (2013). Influencing the crystallization of secondary alloy AlSi6Cu4 with strontium. MANUFACTURING TECHNOLOGY, 2013, vol. 13, no. 1, p. 7-14. ISSN 1213-2489

[8] BOLIBRUCHOVÁ, D., RICHTÁRECH, L. (2013). Study of the gas content in aluminum alloys. MANUFACTURING TECHNOLOGY, 2013, vol. 13, no. 1, p. 14-20. ISSN 1213-2489

[9] EPERJEŠI, L', MALIK, J., EPERJEŠ, Š., FECKO, D. (2013). Influence of returning material on porosity of die castings. MANUFACTURING TECHNOLOGY, 2013, vol. 13, no. 1, p. 36-39. ISSN 1213-2489

[10] BRŮNA, M., KUCHARČÍK, L., SLÁDEK, A. (2013). Complex evaluation of porosity in A356 aluminium alloy using advanced porosity module. MANUFACTURING TECHNOLOGY, 2013, vol. 13, no. 1, p. 26-30. ISSN 1213-2489

[11] GAŠPÁR, Š., PAŠKO, J., MAJERNÍK, J. (2017). Influence of structure adjustment of gating system of casting mould upon the quality of die cast. 1st ed. Lüdenscheid: RAM - Verlag, 2017. 82 p. ISBN 978-3-942303-47-7.

[12] MAJERNÍK, J., KMEC, J., KARKOVÁ, M. (2017). Analysis of the Impact of the Construction of a Gate on the Macroscopic Structure of a Casting and Its Influence on the Mechanical Properties of Castings. MANUFACTURING TECHNOLOGY, 2017, vol. 17, no. 1, p. 62-66. ISSN 1213-2489. 